\title{
Iron metabolism is disturbed and anti-copper treatment improves but does not normalize iron metabolism in Wilson's disease
}

\author{
Grażyna Gromadzka - Diana Wierzbicka - Tomasz Litwin • Adam Przybyłkowski $\mathbb{D}$
}

Received: 7 May 2020/ Accepted: 26 January 2021 / Published online: 8 February 2021

(C) The Author(s) 2021

\begin{abstract}
Wilson's disease (WD) is a rare hereditary disorder of copper metabolism. Some data suggest that iron metabolism is disturbed in WD and this may affect the course of the disease. The current study aimed to determine whether anti-copper treatment could affect iron metabolism in WD. One hundred thirty-eight WD patients and 102 controls were examined. Serum ceruloplasmin and copper were measured by colorimetric enzyme assay or atomic adsorption spectroscopy, respectively. Routine and non-routine parameters of iron metabolism were measured by standard laboratory methods or enzyme immunoassay, respectively. WD patients, both newly diagnosed and treated, had less serum copper and ceruloplasmin than controls $(90.0,63.0,22.0 \mathrm{mg} / \mathrm{dL}$, respectively, $\mathrm{p}<0.001$ ); in the treated patients blood copper and ceruloplasmin were lower than in
\end{abstract}

\section{G. Gromadzka}

Faculty of Medicine, Collegium Medicum, Cardinal Stefan Wyszyński University in Warsaw, Wóycickiego

Str. 1/3, 01-938 Warsaw, Poland

D. Wierzbicka · T. Litwin

Second Department of Neurology, Institute of Psychiatry and Neurology, Sobieskiego Str. 9, 02-957 Warsaw,

Poland

A. Przybyłkowski ( $\square)$

Department of Gastroenterology and Internal Medicine,

Medical University of Warsaw, Banacha Str. 1a,

02-097 Warsaw, Poland

e-mail: aprzybylkowski@wum.edu.pl untreated patients $(\mathrm{p}<0.001)$. Untreated patients $(\mathrm{n}=39)$ had a higher median blood iron $(126.0 \mathrm{vs}$ $103.5 \mathrm{ug} / \mathrm{dL}, \mathrm{p}<0.05)$, ferritin (158.9 vs $47.5 \mathrm{ng} / \mathrm{mL}$, $\mathrm{p}<0.001$ ), hepcidin (32, 6 vs $12.1 \mathrm{ng} / \mathrm{mL}$, $\mathrm{p}<0.001)$ and sTfR (0.8 vs. $0.7 \mathrm{ug} / \mathrm{mL}, \mathrm{p}<0.001)$ and lower blood transferrin $(2.4$ vs. $2.7 \mathrm{~g} / \mathrm{L}$, $\mathrm{p}<0.001), \quad$ TIBC $\quad(303.0 \quad$ vs $338.0 \quad \mathrm{ug} / \mathrm{dL}$, $\mathrm{p}<0.001)$, hemoglobin $(13.1$ vs $13.9 \mathrm{~g} / \mathrm{dL}$, $\mathrm{p}<0.01)$ and RBC (4.3 vs. 4.6, $\mathrm{p}<0.002)$ than controls. Treated patients $(n=99)$ had a significantly lower median iron (88.0 vs. $126.0 \mathrm{ug} / \mathrm{dL}, \mathrm{p}<0.001)$, ferritin (77.0 vs. $158.9 \mathrm{ng} / \mathrm{mL}, \mathrm{p}<0.005)$ and hepcidin (16.7 vs. $32.6 \mathrm{ng} / \mathrm{mL}, \mathrm{p}<001)$ and higher transferrin ( 2.8 vs. $2.4 \mathrm{~g} / \mathrm{L}, \mathrm{p}<0.005)$, TIBC (336.0 vs $303.0 \mathrm{ug} / \mathrm{dL}, \mathrm{p}<0.001)$, RBC (4.8 vs. $4.3 \mathrm{M} / \mathrm{L}$, $\mathrm{p}<0.001)$ and hemoglobin $(14.4$ vs. $13.1 \mathrm{~g} / \mathrm{dL}$, $\mathrm{p}<0.001)$ than untreated; the median iron $(\mathrm{p}<0.005)$ was lower, and ferritin $(\mathrm{p}<0.005)$, RBC $(\mathrm{p}<0.005)$ and hepcidin $(\mathrm{p}<0.002)$ were higher in them than in the control group. Changes in copper metabolism are accompanied by changes in iron metabolism in WD. Anti-copper treatment improves but does not normalize iron metabolism.

Keywords Iron · Copper · Wilson disease 


\section{Introduction}

Wilson's Disease (WD) (Online Mendelian Inheritance in Man [OMIM] Accession Number \# 2779000, also known as hepato-lenticular degeneration, is a rare autosomal recessive disease that mainly manifests with hepatic or neuropsychiatric symptoms. More than 500 mutations have been identified in the $A T P 7 B$ gene that cause intracellular copper transporter ATP-ase 7B (ATP7B) [OMIM * 606882] dysfunction leading to the accumulation of copper mainly in the liver and brain, but also in other organs such as the kidney and brain. In most cases the first symptoms of WD appear in childhood, but sometimes they can appear later even after the age of 60 (Mulligan and Bronstein 2020; Ala et al. 2007; Roberts and Schilsky 2008; Terada et al. 1998; Merle et al. 2007).

Copper and iron metabolism cross over different metabolic pathways. Therefore, clinical symptoms in patients with Wilson's disease can be expected to be due to impaired copper as well as iron metabolism. This may be a consequence of the reduced production and activity of ceruloplasmin, an iron oxidase. Accumulation of copper and iron in the liver was observed in the experimental WD model (Chandarana et al. 2009; Koizumi et al. 1998; Huster et al. 2006; Park et al. 2006). Several human studies have also suggested that in WD iron metabolism may be impaired, and iron accumulation in the liver and/or brain tissue may worsen the clinical course of the disease (Litwin et al. 2013; Pfeiffenberger et al. 2011; Medici and Weiss 2017; Dusek et al. 2017).

Copper-iron interaction in WD should be clarified to better understand disease patomechanism and improve patient treatment. This study is the first that analyzes many parameters of iron metabolism in a relatively large population of patients with Wilson's disease and compares the value of these parameters between untreated patients undergoing decoppering treatment as well as healthy controls.

\section{Patients and methods}

A total of 138 patients with WD, including 39 previously untreated (newly diagnosed with WD) and 99 treated at the Institute of Psychiatry and Neurology in Warsaw, Poland. All patients met WD 8 diagnostic criteria. International Conference Wilson's disease and Menkes' disease (Ferenci et al. 2003). The median duration of treatment in the treated group was 48.5 months (IQR 47.0; range 6-168). Diagnosis of WD was based on the assessment of clinical symptoms (Gromadzka and Czlonkowska 2011; Gromadzka et al. 2011, 2015), abnormal copper metabolism (decreased serum ceruloplasmin (Cp) and serum copper, increased 24-h copper excretion in urine), presence of the Kayser-Fleischer ring and genetic test. In the case of an uncertain diagnosis, the inclusion of Cu64 in ceruloplasmin was measured after 24 and $48 \mathrm{~h}$. All laboratory tests for copper metabolism were performed in the same laboratory using the same standardized methods. The DNA analysis for the three most frequent mutations of $A T P 7 B$ detected in the Polish population was performed using polymerase chain reaction-restriction fragments length polymorphism method (PCR-RFLP) or-if this method did not confirm the presence of two pathogenic $A T P 7 B$ mutations - the DNA sequencing was performed, as previously described (Gromadzka et al. 2005, 2011). Such diagnostic strategy allowed to obtain following results: $70 \mathrm{WD}$ patients $(50.7 \%)$ were homozygous for the c. 3207C > A [p.H1069Q] mutation, 51 (36.9\%) had the c. 3207C > A [p.H1069Q] mutation in one allele and other rare mutation in the second one, and 17 subjects $(12.3 \%)$ had rare mutations in both $A T P 7 B$ alleles. According to the manner in which the disease was manifested, patients were grouped as hepatic or neuropsychiatric. Patients were classified as hepatic when they showed symptoms of chronic or acute liver disease (increased liver enzymes with increased bilirubin in the blood and abnormal INR and/or changes in liver echogenicity; signs of portal hypertension, decompensated liver cirrhosis or acute liver failure) without neuropsychiatric symptoms. Patients were classified as neuropsychiatric when liver disease was accompanied by neurological symptoms such as tremor, dystonia, ataxia, dysarthria, stiffness or mental symptoms, including behavioral disorders, depression, manic psychosis, or cognitive impairment. Several patients were diagnosed as presymptomatic (they were identified thanks to family studies of index cases).

The control group consisted of 102 healthy volunteers with an average age of $35.6 \pm 10.5$ years who had no family history of WD, diagnosed liver disease, neurological or psychiatric disease, chronic inflammatory disease or infectious disease. Control people were recruited from hospital staff and their families. 
The three most common $A T P 7 B$ mutations in the Polish population were absent in these individuals, as documented by DNA sequence analysis using the methods previously described (Gromadzka et al. 2011). Detailed criteria for inclusion and exclusion in the study group are presented in Table 1Blood samples were taken prospectively from all subjects for laboratory analysis. Biological material was collected as separate portions for use in individual measurements to avoid repeated freezing and thawing cycles. Samples were stored at $-70{ }^{\circ} \mathrm{C}$. Samples were used for testing immediately after thawing. All study participants gave written informed consent to participate in this study. The study protocol was approved by the local Ethics Committee and was conducted in accordance with the Code of Ethics of the World Medical Association (Helsinki Declaration) for human experiments.

Serum ceruloplasmin was measured by an enzymatic colorimetric assay as described earlier (Ravin 1961). Serum copper was determined by atomic adsorption spectroscopy using a Shimadzu AA660 instrument.

Routine iron metabolism parameters such as ferritin, transferrin, total iron binding capacity (TIBC), red blood cells (RBC) and hemoglobin (HGB) were measured by standard laboratory methods.

Hepcidin, lactoferrin and soluble transferrin receptor were measured using ELISA kits. Serum lactoferrin was evaluated using the Human Lactoferrin ELISA
Test Kit (catalogue number EL20111-1; Test Pro) with a test range of $0.625-40,000.0 \mathrm{ng} / \mathrm{mL}$. Serum hepcidin level (Hepc) was tested using a hepcidinassociated immunosorbent assay kit (cat. No. SEB979Hu; Cloud Clone Corporation) with a test range of $62.5-4000.0 \mathrm{pg} / \mathrm{mL}$. Serum soluble transferrin receptor (sTfR) was tested using a sandwich enzyme-assay (cat. No. RD194011100; BioVendor;) with a test range of $0.4-2.0 \mu \mathrm{g} / \mathrm{mL}$.

\section{Statistical analysis}

The normality of the analysed continuous variables was determined by Kolmogorov-Smirnov and Lilliefors tests. Data are presented as the mean and standard deviation if they were normally distributed, or as the median and interquartile range if the variables were not normally distributed. Student's $t$ test was used to compare two groups of normally distributed data. The Mann-Whitney U test was used to compare variables that were not normally distributed. Qualitative data is defined as percentage ratios. Comparisons between groups were performed using a Chi square test with Yates correction, if applicable, or Fisher's exact test, when the Chi square test hypothesis was not met. Significance was set at $\mathrm{p}<0.05$. All statistical analyses were performed using the STATISTICA 10.0 software (StatSoft PL, Krakow, Poland).

Table 1 Inclusion and exclusion criteria for the study

\begin{tabular}{|c|c|c|}
\hline & Patients with WD & Control group \\
\hline $\begin{array}{c}\text { Inclusion } \\
\text { criteria }\end{array}$ & $\begin{array}{l}\text { Established WD diagnosis } \\
\text { Age over } 18 \text { years } \\
\text { Written consent to participate in the study }\end{array}$ & $\begin{array}{l}\text { Absence of any disease } \\
\text { Age over } 18 \text { years } \\
\text { Written consent to participate in the study }\end{array}$ \\
\hline $\begin{array}{l}\text { Exclusion } \\
\text { criteria }\end{array}$ & $\begin{array}{l}\text { Prevalence of systemic diseases: cancer, current infection, } \\
\text { hepatitis virus infection } \\
\text { History of blood transfusion performed up to a month before } \\
\text { qualifying for the study } \\
\text { History of iron supplementation up to a year before qualifying } \\
\text { for the study } \\
\text { Alcohol abuse } \\
\text { Lack of consent to participate in the study }\end{array}$ & $\begin{array}{l}\text { Prevalence of systemic diseases: cancer, current } \\
\text { infection, hepatitis virus infection } \\
\text { History of blood transfusion performed up to a } \\
\text { month before study } \\
\text { History of iron supplementation up to a year before } \\
\text { qualifying for the study } \\
\text { Alcohol abuse } \\
\text { Lack of consent to participate in the study } \\
\text { Occurrence of phenotypic traits of WD } \\
\text { The presence of the } A T P 7 B \text { mutation }\end{array}$ \\
\hline
\end{tabular}




\section{Results}

Patient baseline characteristics, including age, type of WD manifestation, presence of the Kayser-Fleisher ring $(\mathrm{KF})$ and copper metabolism parameters are shown in Table 1. The average age of WD patients was $36.7 \times 11.3$ years, which was similar to the age of control (33.5 vs. 5.9 years, $\mathrm{p}<0.09$ ). The two groups were similar in terms of gender distribution (chi2 0.003, df 1, p < 0.95). Patients included in the untreated and treated groups did not differ in age and sex (Table 2). WD patients, both untreated and receiving therapy, had significantly lower serum copper (63.0 vs 22.0 vs $90.0 \mu \mathrm{g} / \mathrm{dL}, \mathrm{p}<0.001)$ and ceruloplasmin than controls ( 15.3 vs 5.4 vs $31.8 \mathrm{mg} /$ $\mathrm{dL}, \mathrm{p}<0.001$, Table 3 ). The blood concentration of copper and ceruloplasmin in treated patients were lower than in untreated patients, as shown in Table 3 .

Untreated patients had statistically significant higher concentration of ferritin than patients on treatment (158.9 vs $77.0 \mathrm{ng} / \mathrm{mL}, \mathrm{p}<0.005)$. Patients form both groups however had higher ferritin concentration than controls 47,5 ng/mL, p $<0.005$, Table 4).

Iron concentration was noteworthy lower in treated patients than in treatment naive $(88.0 \mathrm{vs} 126.0 \mathrm{ug} / \mathrm{dL}$, $\mathrm{p}<0.001$, Table 4). Treated patients presented lower iron values than controls $(88.0$ vs $103.5 \mu \mathrm{g} / \mathrm{dL}$ $\mathrm{p}<0.002)$. Hepcidin concentration was highest in untreated patients, lower in treated group (32.6 vs $16.7 \mathrm{ng} / \mathrm{mL}, \mathrm{p}<0.001)$ and lowest in controls (12.1 ng/mL, $\mathrm{p}<0.001)$. Red blood cells count and haemoglobin concentration were highest in patients on treatment, lower in controls (RBC 4.6 vs $4.8 \mathrm{M} / \mathrm{L}$ $\mathrm{p}<0.005$, hemoglobin 13.9 vs $14,4 \mathrm{~g} / \mathrm{dL} \mathrm{p}<0.064)$ and lowest in patients without treatment (RBC $4.3 \mathrm{M} /$ $\mathrm{L}$, hemoglobin $13.1 \mathrm{~g} / \mathrm{dL}$ ). Lactoferrin concentration did not differ significantly between study groups.

Transferrin concentration was higher in treated patients than untreated ( 2.8 vs $2.4 \mathrm{~g} / \mathrm{L}, \mathrm{p}<0.005)$, it was also higher in controls than in untreated group (2.75 vs $2.4 \mathrm{~g} / \mathrm{L} \mathrm{p}<0.001)$, meanwhile soluble transferrin receptor concentration was lower in controls than in the group of untreated patients ( 0.7 vs 0.8 , $\mathrm{p}<0.001)$. The two groups of patients did not differ in term of sTfR concentration (Table 4). Total iron binding capacity was highest in controls, significantly lower in untreated WD population (338.0 vs 303.0 $\mathrm{p}<0.001$ ), with notably difference between treated group and untreated group (336.0 vs 303.0, $\mathrm{p}<0.001$, Table 4).

Table 2 Clinical and laboratory characteristics of studied population

\begin{tabular}{|c|c|c|c|c|}
\hline Characteristics & Controls & Untreated patients & Patients on treatment & $\mathrm{p}$ \\
\hline Number of persons (n) & 102 & 39 & 99 & - \\
\hline Age at onset of WD (median (IQR)) & $31.0(8.0)$ & $34.5(18.5)$ & $33.0(14.0)$ & $\begin{array}{l}\text { (a) }<0.07 \\
\text { (b) }<0.18 \\
\text { (c) }<0.84\end{array}$ \\
\hline Sex. female/male (n (\%)) & $51 / 51(50 / 0)$ & $23 / 16(59 / 41)$ & $41 / 58(41 / 59)$ & $\begin{array}{l}\text { (a) }<0.34 \\
\text { (b) }<0.22 \\
\text { (c) }<0.06\end{array}$ \\
\hline Patients treated with D-penicylamine/zinc sulphate (n $(\%)$ ) & - & - & $50 / 49(50.5 / 49.5)$ & - \\
\hline Time of treatment, months (median (IQR)) & - & - & $54.5(58.0)$ & - \\
\hline Clinical phenotype of WD (n (\%)) & - & & & \\
\hline Hepatic & & $11(34.4)$ & $25(25.2)$ & $<0.58$ \\
\hline Neuropsychiatric & & $18(56.2)$ & $65(65.7)$ & \\
\hline Presymptomatic & & $3(9.4)$ & $9(9.1)$ & \\
\hline No data & & 7 & - & \\
\hline
\end{tabular}

$I Q R$ interquartile range, $S D$ standard deviation

*p values for the comparison between untreated and treated patients with WD 
Table 3 Markers of copper metabolism in WD patients and healthy controls

\begin{tabular}{|c|c|c|c|c|}
\hline Parameter & $\begin{array}{l}\text { Controls } \\
(\mathrm{n}=102)\end{array}$ & $\begin{array}{l}\text { Untreated patients } \\
(\mathrm{n}=39)\end{array}$ & $\begin{array}{l}\text { Patients on treatment } \\
(\mathrm{n}=99)\end{array}$ & $\mathrm{p}$ \\
\hline Serum copper $(\mu \mathrm{g} / \mathrm{dL})(\text { median }(\mathrm{IQR}))^{\mathbf{f}}$ & $90.0(26.0)$ & $63.0(17.0)$ & $22.0(35.0)$ & $\begin{array}{l}\text { (a) }<0.001 \\
\text { (b) }<0.001 \\
\text { (c) }<0.001\end{array}$ \\
\hline $\begin{array}{l}\text { Serum ceruloplasmin }(\mathrm{mg} / \mathrm{dL}) \text { (median } \\
(\mathrm{IQR}))\end{array}$ & $31.8(10.7)$ & $15.3(8.0)$ & $5.4(6.7)$ & $\begin{array}{l}\text { (a) }<0.001 \\
\text { (b) }<0.001 \\
\text { (c) }<0.001\end{array}$ \\
\hline
\end{tabular}

$I Q R$ interquartile range

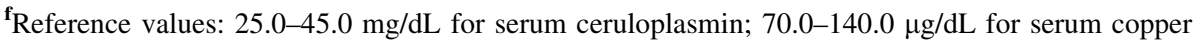

(a) $\mathrm{p}$ for the comparison between untreated and treated patients; (b) $\mathrm{p}$ for the comparison between treated patients and controls; (c) $\mathrm{p}$ for the comparison between untreated patients and controls

\section{Discussion}

The presented results showed that iron metabolism is disturbed in WD. We document that both newly diagnosed and treated patients present iron metabolism abnormalities that were more apparent in the untreated group. Before start of treatment, patients with WD had higher concentration of iron, ferritin and hepcidin, and lower blood transferrin, TIBC, HGB, and RBC than controls. In our opinion, most of these abnormalities may results from hepatitis (Morgan and Philip 2002). Inflammation is associated with changes in the synthesis of so-called acute phase proteins (APP), whose production increases (positive APP) or decreases (negative APP) during inflammation. Ferritin and hepcidin belong to the positive APP group, the production of which increases, while transferrin represents negative APP, the concentration of which decreases in inflammation. Since circulating iron is bound mainly to transferrin, the TIBC value is an indirect measure of the concentration of this protein .

In our view, lower than in the control group, red blood cell counts and hemoglobin levels in untreated patients may be due to copper toxicity. An excess of free copper in the blood can stimulate the production of reactive oxygen species, oxidation of red blood cells, and finally impaired function and shortened survival (Ward et al. 2014; Morris et al. 1995; Harris et al. 1998).

There was no difference in blood lactoferrin between untreated patients and the control group. This was an unexpected result because the concentration of this protein increases during excessive iron intake as well as inflammation. However, as Brock suggests, excess lactoferrin is removed very quickly from the blood (24-48 h) by macrophages and monocytes, and then the iron associated with lactoferrin is converted to ferritin (Adlerova et al. 2008; Brock 2002).

We observed that transferrin, hemoglobin, TIBC, lactoferrin and STfR normalized on WD treatment. The hepcidin and ferritin remained elevated, but both were lower in the treatment group than in the untreated group. The reduction of ferritin and hepcidin and the increase in TIBC in treated patients may be interpreted as a marker of resolution of hepatitis due to decoppering treatment. Lower hepcidin concentration in treated patients than in untreated may also be associated with normalization of iron metabolism resulting from decoppering treatment and therefore-a mechanism to prevent iron overload including hepcidin activity, may no longer needed. Unexpectedly treated patients had higher red blood cell counts and lower iron levels than control and untreated patients. This may be due to greater erythropoietic activity or other-yet undiscovered-mechanisms.

We have not presented results of copper and iron status according to phenotype. In both clinical phenotype of the disease i.e. hepatic and neuropsychiatric liver is affected. We have performed such analysisthere was no significant differences between groups. The differences of copper and iron metabolism between female and male patients with WD have 
Table 4 Markers of iron metabolism in WD patients and healthy controls

\begin{tabular}{|c|c|c|c|c|}
\hline Parameter & $\begin{array}{l}\text { Controls } \\
(\mathrm{n}=102)\end{array}$ & $\begin{array}{l}\text { Untreated patients } \\
(\mathrm{n}=39)\end{array}$ & $\begin{array}{l}\text { Patients on treatment } \\
(\mathrm{n}=99)\end{array}$ & $\mathrm{p}$ \\
\hline Ferritin (ng/mL) (median (IQR)) & $47.5(83.0)$ & $158.9(257.9)$ & $77.0(108.0)$ & $\begin{array}{l}\text { (a) }<0.005 \\
\text { (b) }<0.005 \\
\text { (c) }<0.001\end{array}$ \\
\hline Hemoglobin (g/dL) (median (IQR)) & $13.9(2.0)$ & $13.1(1.4)$ & $14.4(2.1)$ & $\begin{array}{l}\text { (a) }<0.001 \\
\text { (b) }<0.064 \\
\text { (c) }<0.010\end{array}$ \\
\hline Hepcidin (ng/mL) (median (IQR)) & $12.1(15.8)$ & $32.6(47.2)$ & $16.7(26.0)$ & $\begin{array}{l}\text { (a) }<0.001 \\
\text { (b) }<0.002 \\
\text { (c) }<0.001\end{array}$ \\
\hline Iron $(\mu \mathrm{g} / \mathrm{dL})(\operatorname{median}(\mathrm{IQR}))$ & $103.5(52.0)$ & $126.0(58.0)$ & $88.0(51.0)$ & $\begin{array}{l}\text { (a) }<0.001 \\
\text { (b) }<0.005 \\
\text { (c) }<0.052\end{array}$ \\
\hline Lactoferrin (ng/mL) (median (IQR)) & $295.5(110.0)$ & $326.0(221.0)$ & $289.0(166.0)$ & $\begin{array}{l}\text { (a) }<0.091 \\
\text { (b) }<0.738 \\
\text { (c) }<0.084\end{array}$ \\
\hline $\begin{array}{l}\text { Red blood cells }(\mathrm{M} / \mathrm{L}) \text { (median } \\
(\mathrm{IQR}))\end{array}$ & $4.6(0.7)$ & $4.3(0.9)$ & $4.8(0.7)$ & $\begin{array}{l}\text { (a) }<0.001 \\
\text { (b) }<0.005 \\
\text { (c) }<0.002\end{array}$ \\
\hline TIBC $(\mu \mathrm{g} / \mathrm{dL})($ median $(\mathrm{IQR}))$ & $338.0(54.0)$ & $303.0(103.8)$ & $336.0(80.0)$ & $\begin{array}{l}\text { (a) }<0.001 \\
\text { (b) }<0.075 \\
\text { (c) }<0.001\end{array}$ \\
\hline $\operatorname{sTfR}(\mu \mathrm{g} / \mathrm{mL})(\operatorname{median}(\mathrm{IQR}))$ & $0.7(0.3)$ & $0.8(0.5)$ & $0.8(0.5)$ & $\begin{array}{l}\text { (a) }<0.159 \\
\text { (b) }<0.106 \\
\text { ((c) }<0.001\end{array}$ \\
\hline Transferrin (g/L) (median (IQR)) & $2.75(0.54)$ & $2.4(0.8)$ & $2.8(0.7)$ & $\begin{array}{l}\text { (a) }<0.005 \\
\text { (b) }<0.722 \\
\text { ((c) }<0.001\end{array}$ \\
\hline
\end{tabular}

$I Q R$ interquartile range

(a) $\mathrm{p}$ for the comparison between untreated and treated patients; (b) $\mathrm{p}$ for the comparison between treated patients and controls; (c) $\mathrm{p}$ for the comparison between untreated patients and controls; IQR, interquartile range

been analyzed in a separate study (Gromadzka et al. 2020).

We are aware that although we analyzed a relatively large number of patients, the number of untreated patients was small and probably due to this a few of the observed differences did not reach statistical significance. Therefore, more studies are needed to verify the presented results

In summary, our findings indicate that changes in copper metabolism are accompanied by changes in iron metabolism in WD; anti-copper drug treatment restores, but does not normalize iron metabolism in patients with WD. Further research is needed to determine the optimal methods for control and normalization of iron metabolism in patients with WD.

Acknowledgements We thank all those who have helped in carrying out the research. We are grateful to all the patients and individuals for their participation in this study. We would also like to thank hospital staff who contributed to the blood sample collection for this study as well as to all clinicians who were involved in patients' diagnostics/phenotyping.

Author contributions GG: conceptualization; data curation; formal analysis, funding acquisition; investigation, methodology, project administration, supervision; writing: 
review and editing. DW: investigation, methodology, writing: original draft. PA: fomal analysis, writing: review and editing. TL: data curation, investigation, methodology; writing: review.

Funding The study was supported by Polish National Science Center, Grant No N N402 471640.

Availability of data and material All study data are available at request- contact to corresponding author.

\section{Compliance with ethical standards}

Conflict of interest All authors disclose any financial and personal relationships with other people or organizations that could inappropriately influence (bias) th work.

Consent to participate All participants gave their informed consent before taking part in a study.

Consent for publication All authors gave their consent for publication.

Ethics approval The study protocol was approved by the local Ethics Committee and has been carried out in accordance with The Code of Ethics of the World Medical Association (Declaration of Helsinki) for experiments involving humans.

Open Access This article is licensed under a Creative Commons Attribution 4.0 International License, which permits use, sharing, adaptation, distribution and reproduction in any medium or format, as long as you give appropriate credit to the original author(s) and the source, provide a link to the Creative Commons licence, and indicate if changes were made. The images or other third party material in this article are included in the article's Creative Commons licence, unless indicated otherwise in a credit line to the material. If material is not included in the article's Creative Commons licence and your intended use is not permitted by statutory regulation or exceeds the permitted use, you will need to obtain permission directly from the copyright holder. To view a copy of this licence, visit http://creativecommons.org/licenses/by/4.0/.

\section{References}

Adlerova L, Bartoskova A, Faldyna M (2008) Lactoferrin: a review. Vet Med 53:457-468

Ala A, Walker AP, Ashkan K, Dooley JS, Schilsky M (2007) Wilson's disease. Lancet 369:397-408

Brock JH (2002) The physiology of lactoferrin. Biochem Cell Biol 80:1-6. https://doi.org/10.1139/o01-212

Chandarana H, Lim RP, Jensen JH, Hajdu CH, Losada M, Babb JS, Huffman S, Taouli B (2009) Hepatic iron deposition in patients with liver disease: preliminary experience with breath-hold multiecho T2*-weighted sequence. Am J Roentgenol 193:1261-1267. https://doi.org/10.2214/ajr. 08.1996

Dusek P, Bahn E, Litwin T, Jabłonka-Salach K, Łuciuk A, Huelnhagen T, Madai VI, Dieringer MA, Bulska E, Knauth
M, Niendorf T, Sobesky J, Paul F, Schneider SA, Czlonkowska A, Brück W, Wegner C, Wuerfel J (2017) Brain iron accumulation in Wilson disease: a post mortem 7 Tesla MRI-histopathological study. Neuropathol Appl Neurobiol 43:514-532. https://doi.org/10.1111/nan.12341

Ferenci P, Caca K, Loudianos G, Mieli-Vergani G, Tanner S, Sternlieb I, Schilsky M, Cox D, Berr F (2003) Diagnosis and phenotypic classification of Wilson disease. Liver Int 23:139-142. https://doi.org/10.1034/j.1600-0676.2003. 00824.x

Gromadzka G, Członkowska A (2011) Influence of IL-1RN intron 2 variable number of tandem repeats (VNTR) polymorphism on the age at onset of neuropsychiatric symptoms in Wilson's disease. Int J Neurosci 121:8-15. https://doi.org/10.3109/00207454.2010.523131

Gromadzka G, Schmidt HH, Genschel J, Bochow B, Rodo M, Tarnacka B, Litwin T, Chabik G, Członkowska A (2005) Frameshift and nonsense mutations in the gene for ATPase7B are associated with severe impairment of copper metabolism and with an early clinical manifestation of Wilson's disease. Clin Genet 68:524-532. https://doi.org/ 10.1111/j.1399-0004.2005.00528.x

Gromadzka G, Rudnicka M, Chabik G, Przybyłkowski A, Członkowska A (2011) Genetic variability in the methylenetetrahydrofolate reductase gene (MTHFR) affects clinical expression of Wilson's disease. J Hepatol 55:913-919. https://doi.org/10.1016/j.jhep.2011.01.030

Gromadzka G, Kruszyńska M, Wierzbicka D, Litwin T, Dzieżyc K, Wierzchowska-Ciok A, Chabik G, Członkowska A (2015) Gene variants encoding proteins involved in antioxidant defense system and the clinical expression of Wilson disease. Liver Int 35:215-222. https://doi.org/10. 1111/liv.12493

Gromadzka G, Wierzbicka D, Litwin T, Przybyłkowski A (2020) Difference in iron metabolism may partly explain sex-related variability in the manifestation of Wilson's disease. J Trace Elem Med Biol 62:126637. https://doi.org/ 10.1016/j.jtemb.2020.126637

Harris ZL, Klomp LW, Gitlin JD (1998) Aceruloplasminemia: an inherited neurodegenerative disease with impairment of iron homeostasis. Am J Clin Nutr 67:5972-5977. https:// doi.org/10.1093/ajen/67.5.972s

Huster D, Finegold MJ, Morgan CT, Burkhead JL, Nixon R, Vanderwerf SM, Gilliam CT, Lutsenko S (2006) Consequences of copper accumulation in the livers of the Atp7b -/- (Wilson disease gene) knockout mice. Am J Pathol 168:423-434. https://doi.org/10.2353/ajpath.2006. 050312

Koizumi M, Fujii J, Suzuki K, Inoue T, Inoue T, Gutteridge JM, Taniguchi N (1998) A marked increase in free copper levels in the plasma and liver of LEC rats: an animal model for Wilson disease and liver cancer. Free Radic Res 28:441-450. https://doi.org/10.3109/10715769809066881

Litwin T, Gromadzka G, Szpak GM, Jablonka-Salach K, Bulska E (2013) Brain metal accumulation in Wilson's disease. J Neurol Sci 329:55-58. https://doi.org/10.1016/j.jns.2013. 03.021

Medici V, Weiss KH (2017) Genetic and environmental modifiers of Wilson disease. Handb Clin Neurol 142:35-41. https://doi.org/10.1016/b978-0-444-63625-6.00004-5 
Merle U, Schaefer M, Ferenci P, Stremmel W (2007) Clinical presentation, diagnosis and long-term outcome of Wilson' disease: a cohort study. Gut 56:115-120. https://doi.org/10. 1136/gut.2005.087262

Morgan E, Philip O (2002) Mechanisms and regulation of intestinal iron absorption. Blood Cells Mol Dis 29:384-399. https://doi.org/10.1006/bcmd.2002.0578

Morris CJ, Earl JR, Trenam CW, Blake DR (1995) Reactive oxygen species and iron-a dangerous partnership in inflammation. Int J Biochem Cell Biol 27:109-122. https:// doi.org/10.1016/1357-2725(94)00084-o

Mulligan C, Bronstein JM (2020) Wilson disease: an overview and approach to management. Neurol Clin 38:417-432. https://doi.org/10.1016/j.ncl.2020.01.005

Park SM, Vo K, Lallier M, Cloutier AS, Brochu P, Alvarez F, Martin SR (2006) Hepatocyte transplantation in the Long Evans Cinnamon rat model of Wilson's disease. Cell Transpl 15:13-22. https://doi.org/10.3727/ 000000006783982188

Pfeiffenberger J, Gotthardt DN, Herrmann T, Seessle J, Merle U, Schirmacher P, Stremmel W, Weiss KH (2011) Iron metabolism and the role of HFE gene polymorphism in
Wilson disease. Liver Int 32:165-170. https://doi.org/10. 1111/j.1478-3231.2011.02661

Ravin HA (1961) An improved colorimetric assay of ceruloplasmin. J Lab Clin Med 58:161-168

Roberts EA, Schilsky ML (2008) Diagnosis and treatment of Wilson disease: an update. Hepatology 47:2089-2111. https://doi.org/10.1016/S0140-6736(07)60196-2

Sorbello O, Sini M, Civolani A, Demelia L (2010) HFE gene mutations and Wilson's disease in Sardinia. Dig Liver Dis 42:216-219. https://doi.org/10.1016/j.dld.2009.06.012

Terada K, Schilsky ML, Miura N (1998) ATP7B (WND) protein. Int J Biochem Cell Biol 30:1063-1067. https://doi. org/10.1016/s1357-2725(98)00073-9

Ward RJ, Zucca FA, Dyan JH, Grichton RG, Zecca L (2014) The role of iron in brain ageing and neurodegenerative disorders. Lancet Neurol 13:1045-1060. https://doi.org/10. 1016/s1474-4422(14)70117-6

Publisher's Note Springer Nature remains neutral with regard to jurisdictional claims in published maps and institutional affiliations. 